\title{
Characterization of Prostate Cancer in a Functional Eunuch
}

John J. Stocking, MA a,*; Michael V. Fiandalo, PhD a,"; Elena A. Pop, MDa; John H. Wilton, PhD Gissou Azabdaftari, $\mathrm{MD}^{\mathrm{c}}$; and James L. Mohler, $\mathrm{MD}^{\mathrm{a}}$

\section{Abstract}

Background: Eunuchs rarely, if ever, develop prostate cancer (CaP). This article reports on a 62-year-old functional eunuch from prepubertal mumps orchitis who developed clinically localized CaP. Methods: Serum and CaP and benign prostate tissue androgen levels were measured using a validated liquid chromatography-tandem mass spectrometry assay. The assay measures testosterone; dihydrotestosterone (DHT); the adrenal androgens, androstenedione and dehydroepiandrosterone; and the androgen metabolites, androsterone and androstanedione. Gene and protein expression levels of androgen metabolism enzymes, and androgen receptor and androgen-regulated genes were measured using quantitative reverse-transcription polymerase chain reaction and immunohistochemistry, respectively. Results: Intracrine androgen metabolism produced tissue DHT when serum and tissue testosterone levels were castrate and undetectable, respectively. Androgen receptor, androgen-regulated, and androgen metabolism enzyme genes were expressed but at lower levels in CaP than benign tissues. Conclusions: DHT was synthesized using the primary backdoor androgen metabolism pathway and not using androstenedione or dehydroepiandrosterone via the frontdoor or secondary backdoor pathways.

J Natl Compr Canc Netw 2016;14(9):1054-1060

\section{Background}

Prostate cancer $(\mathrm{CaP})$ is the second leading cause of cancer-related death in men. ${ }^{1} \mathrm{CaP}$ growth relies on the interaction between the androgen receptor (AR) and its ligands, testosterone and dihydrotestosterone (DHT). ${ }^{2}$ Most men who present with advanced $\mathrm{CaP}$ or who do not experience response to curative therapy receive androgen deprivation therapy. This therapy diminishes testosterone and DHT levels that inactivate AR, which induces tumor regression. ${ }^{3,4}$ The castration-recurrent/resistant phenotype (CRPC) is characterized by androgen deprivation therapy failure and $\mathrm{CaP}$ recurrence. One mechanism for AR activation in CRPC is intratumoral intracrine metabolism of weak adrenal androgens to testosterone or $\mathrm{DHT}^{5}$ via 1 or more of 3 pathways to DHT (Figure

From the Departments of a Urology, bPharmacology and Therapeutics, and 'Pathology, Roswell Park Cancer Institute, Buffalo, New York.

*These authors contributed equally to this manuscript.

Submitted January 22, 2016; accepted for publication June 1, 2016.

The authors have disclosed that they have no financial interests,

arrangements, affiliations, or commercial interests with the manufacturers

of any products discussed in this article or their competitors.

Author Contributions: Radical prostatectomy procedure: Mohler.

Supervision of experiment completion, data analysis, and manuscript
1A). The frontdoor pathway uses adrenal androgens, dehydroepiandrosterone (DHEA), or $\Delta 4$ androstenedione (ASD) to make testosterone, and $5 \alpha$-reductases (SRD5A) reduce testosterone to DHT. The primary backdoor pathway's terminal step uses $3 \alpha$-oxidoreductases to convert $5 \alpha$-androstane- $3 \alpha, 17 \beta$-diol to DHT. The secondary backdoor pathway requires both SRD5A and $3 \alpha$-oxidoreductase enzyme activity to generate DHT. ${ }^{6-9}$

This article reports on a patient who experienced mumps orchitis at 13 years of age, before or at the onset of puberty. He developed secondary sex characteristics poorly; his body habitus is eunochoid and he shaves monthly. He was married briefly and never fathered a child. Hypertension has been controlled medically since 51 years of age. He started testosterone replacement therapy (TRT) to treat hypogonadal symptoms at

development: Mohler. Execution of experiments, data analysis, manuscript development: Stocking and Fiandalo. Acquisition of paraffin-embedded tissues and performance of immunohistochemistry: Pop. Performance of all mass spectrometry measurements: Wilton. Characterization of prostate tissue: Azabdaftari. Assistance with data analysis: Wilton and Asabdaftari.

Correspondence: James L. Mohler, MD, Department of Urology, Roswell Park Cancer Institute, Elm and Carlton Streets, Buffalo, NY 14263.

E-mail: James.Mohler@RoswellPark.org 
age 60 years when his prostate examination was benign, prostate-specific antigen (PSA) level was 0.43 $\mathrm{mcg} / \mathrm{dL}$ (Table 1), and PSA doubling time was 3.18 years. Transrectal ultrasound-guided prostate biopsy was performed at the start of TRT because high-grade prostatic intraepithelial neoplasia was identified in a single prostate biopsy core in 2009 and his PSA level had increased from 0.2 to 0.43 . TRT was halted when prostate ultrasound revealed a 15-gram prostate, and prostate biopsy results found Gleason score of $4+4=8$ in $30 \%$ of the right mid-medial core and Gleason score of $3+4=7$ in $5 \%$ and $15 \%$ of the right base lateral and right apex lateral cores, respectively. Bone scan showed no evidence of metastasis. Serum testosterone measured in
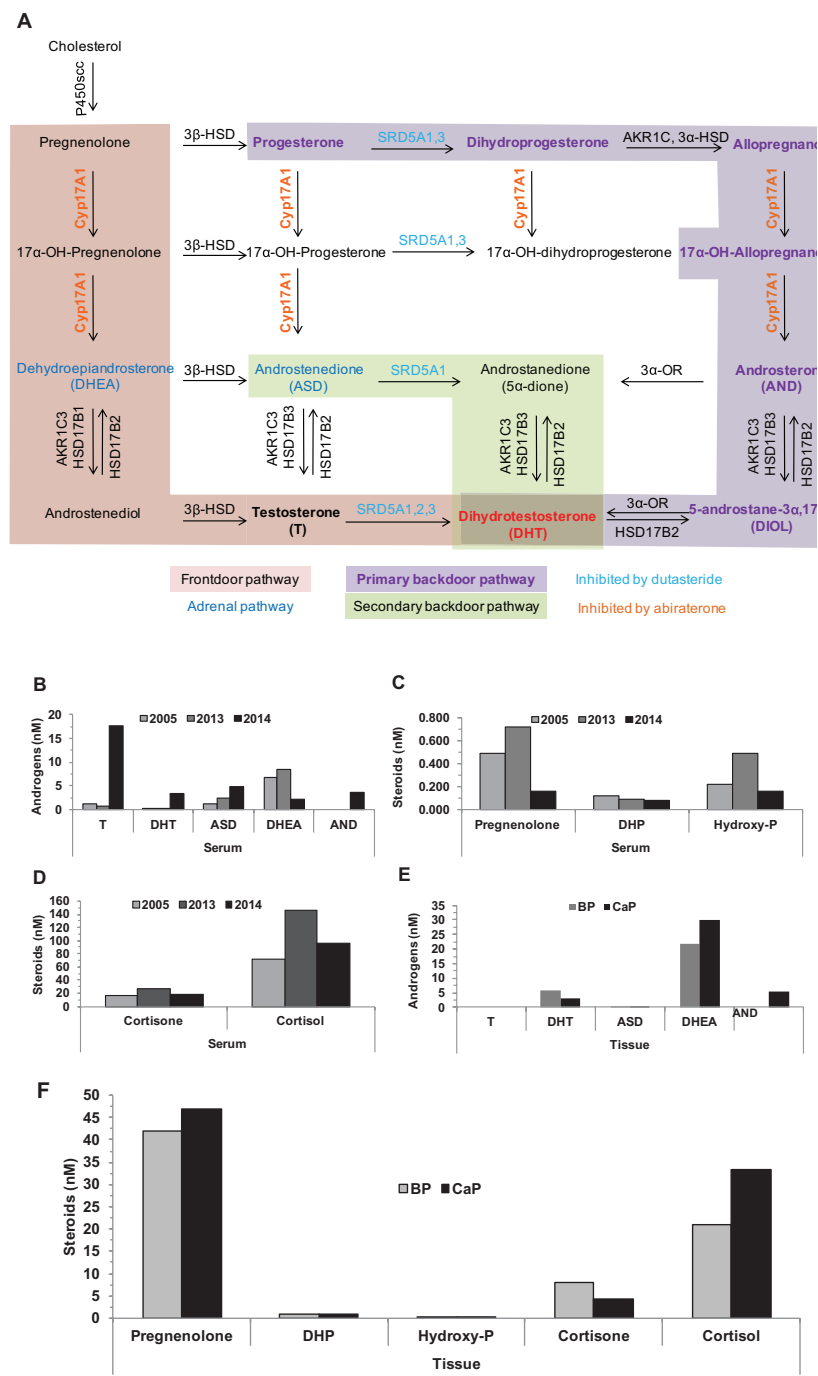

Figure 1. Androgen metabolism characterization. Three pathways for DHT synthesis (A), and serum (B-D) and tissue $(E, F)$ steroid levels. Abbreviations: AND, androsterone; ASD, $\triangle 4$ androstenedione; $B P$, benign prostate; CaP, protate cancer; DHEA, dehydroepiandrosterone; DHP, dihydroprogesterone; DHT, dihydrotestosterone; Hydroxy-P, hydroxypregnenolone; $\mathrm{T}$, testosterone. the castrate range (Table 1). Robotic left nerve-sparing, right extrafascial radical prostatectomy, and right pelvic lymph node dissection revealed Gleason grade 3+4=7 adenocarcinoma that occupied $5 \%$ of a 20 -gram prostate. Gleason grade was overestimated due to prostate biopsy undersampling, which occurs rarely. ${ }^{9}$ Pathologic stage was T3aNOMO and surgical margins were negative. PSA was undetectable 8 weeks later.

PSA remained undetectable for 3 months after radical prostatectomy, and the patient resumed TRT to treat hypogonadism. The 62-year-old patient shows no clinical or biochemical evidence of disease 2 years after radical prostatectomy, with low detectable or undetectable PSA levels despite a TRT-related increase in serum androgen levels.

This case study is important because the patient appeared to have had lifelong castrate or near-castrate androgen levels but developed $\mathrm{CaP}$. This is the second reported case of a eunuch diagnosed with $\mathrm{CaP}$, which prompted full characterization of the androgen axis.

\begin{tabular}{|lccl|}
\hline Table 1. Clinical Summary \\
\hline Date & $\begin{array}{c}\text { PSA } \\
\text { (ng/mL) }\end{array}$ & $\begin{array}{c}\text { T } \\
\text { (ng/dL) }\end{array}$ & Treatment \\
\hline $9 / 09$ & 0.2 & & $\begin{array}{l}\text { Biopsy for abnormal DRE } \\
\text { revealed HGPIN in 1 of } \\
\text { 12 cores }\end{array}$ \\
\hline $4 / 10$ & 0.2 & & \\
\hline $6 / 11$ & 0.43 & & \\
\hline $3 / 12$ & 0.3 & & \\
\hline $5 / 13$ & 0.43 & 47 & $\begin{array}{l}\text { DRE normal, started TRT, } \\
\text { scheduled biopsy }\end{array}$ \\
\hline $6 / 13$ & & 533 & $\begin{array}{l}\text { Biopsy revealed Gleason } \\
\text { grade 4+4=8 CaP; TRT } \\
\text { stopped }\end{array}$ \\
\hline $9 / 13$ & & & Radical prostatectomy \\
\hline $11 / 13$ & $<0.03$ & & \\
\hline $12 / 13$ & $<0.03$ & 23 & Restarted TRT \\
\hline $1 / 14$ & $<0.03$ & 162 & \\
\hline $5 / 14$ & & 661 & \\
\hline $8 / 14$ & 0.05 & 1026 & \\
\hline $2 / 15$ & $<0.03$ & 929 & \\
\hline $8 / 15$ & 0.04 & 496 & \\
\hline $2 / 16$ & 0.06 & 314 & \\
\hline & & & \\
\hline
\end{tabular}

Abbreviations: CaP, prostate cancer; DRE, digital rectal examination; HGPIN, high-grade prostatic intraepithelial neoplasia; PSA, prostatespecific antigen; T, testosterone; TRT, testosterone replacement therapy. 
Stocking et al

\section{Methods}

\section{Biospecimens}

Tissue was procured as described, ${ }^{11}$ with modifications (see supplemental eAppendix 1, available with this article at JNCCN.org). Prostate tissue collected at radical prostatectomy was frozen and used for liquid chromatography-tandem mass spectrometry (LC-MS/MS) or quantitative reverse-transcription polymerase chain reaction (qRT-PCR). Biopsy tissue was formalin-fixed paraffin-embedded for immunohistochemistry. Serum was collected in 2005, 2013, and 2014 for LC-MS/MS.

\section{Liquid Chromatography-Tandem Mass Spectrometry}

Serum and prostate samples were analyzed over 3 runs for 6 androgens (testosterone, DHT, DHEA, ASD, androsterone [AND], and $5 \alpha$-androstanedione [ $5 \alpha$-dione]) using a modification of a validated LCMS/MS method. ${ }^{12} 5 \alpha$-dione was measured but not validated in the original method. Sample extraction was performed using a 250 - mcL aliquot of a calibrator, quality control, serum blank, or study sample (serum or prostate homogenate) with $750 \mathrm{mcL}$ of HPLC-grade water, $100 \mathrm{mcL}$ internal standard solution $(75.0 / 225 \mathrm{pg} / \mathrm{mL} \mathrm{d} 3-\mathrm{T} / \mathrm{d} 3-\mathrm{DHT}$ in $75 \%$ methanol in water), and $4.0 \mathrm{~mL}$ methyl-tert-butyl ether (MTBE; Omnisolve, EMD Milipore, Billerica, MA). Tubes were vortexed, rotated for 15 minutes, and centrifuged using a Sorvall, model RT6000B centrifuge (Thermo Scientific, Grand Island, NY), at 2,800 $\mathrm{rpm}$ at $4^{\circ} \mathrm{C}$ for 15 to 30 minutes to separate liquid phases. The aqueous phase was frozen in a dry ice/acetone bath. The MTBE layer was poured into a clean glass conical tube, MTBE was evaporated at $37^{\circ} \mathrm{C}$ with nitrogen, and the residue was reconstituted in 60\% methanol. The suspension was centrifuged using a Heraeus Multifuge X3R centrifuge (Thermo Scientific) at $2,800 \mathrm{rpm}$ at $4^{\circ} \mathrm{C}$ for 5 minutes and an aliquot of the supernatant was injected into the mass spectrometer. LC-MS/MS was performed using a Prominence UFLC System (Shimadzu Scientific Instruments, Kyoto, Japan) and a QTRAP 5500 mass spectrometer (AB Sciex, Framingham, MA) with an electrospray ionization source and two 10 . port switching valves (Valco instruments Co. Inc., Houston, TX; model EPC10W). Androgens were quantitated using prespiked calibration standards, and quality control samples were prepared in char- coal-stripped postmenopausal female serum (Bioreclamation, LLC, Westbury, NY).

Extracted samples were reinjected and chromatographed using a 28-minute gradient profile to examine 12 additional steroids in a semiquantitative manner. Steroids were quantitated using a single extracted serum calibrator that contained dihydroprogesterone, estrone, estradiol, cortisol, hydroxypregnenolone, hydroxyprogesterone, deoxycorticosterone, corticosterone, cortisone, aldosterone, or allopregnanolone, each at a concentration of 888 $\mathrm{pg} / \mathrm{mL}$, and pregnenolone at $307 \mathrm{pg} / \mathrm{mL}$. Back-calculated concentration estimates of unknowns were obtained using slopes from the single-point serum calibrators forced through 0 . Identification of the other 12 steroids in the study samples was based on specific mass spectral multiple reaction monitoring transitions and correlation of retention times with authentic standards. Lower limits of quantitation (LLOQ) cutoffs were estimated at a signal-to-noise ratio of 5 and depended on sensitivity. The approach provided an efficient semiquantitative screening technique for additional steroids to assess concentration differences between benign prostate (BP) and $\mathrm{CaP}$ tissues.

Serum calibration ranges and LLOQ are listed in supplemental eTable 1, and calibrator and quality control accuracy are listed in supplemental eTables 2 and 3, respectively. Acceptance criteria for accuracy and precision for testosterone, DHT, ASD, DHEA, and AND followed the FDA's bioanalytical guidance requirements, ${ }^{13}$ except for $5 \alpha$-dione, which was allowed $\pm 25 \%$ for quality control (supplemental eTables 2 and 3). Correlation coefficients for all calibration curves were 0.9936 or greater. Data were represented as nM and were calculated by converting ng/g (ng/g $=\{[$ (ng steroid/mL homogenate) x (mL homogenate)] / (g tissue used in homogenate $)\}$ to $\mathrm{nM}(\mathrm{nM}=\{[(\mathrm{ng} / \mathrm{g}) *$ (1000 pg/ng)]/(pg analyte/pmol)\}).

\section{Quantitative Reverse-Transcription Polymerase Chain Reaction}

$\mathrm{CaP}$ and BP tissues were Dounce homogenized, tissue lysates were passed through QIAshredder columns, and RNA was extracted using the RNeasy Plus Mini Kit (Qiagen, Valencia, CA). Genomic DNA contamination was assessed using qualitative PCR using intron-spanning glyceraldehyde 3-phopsphate dehydrogenase (GAPDH) primers. Genomic DNA con- 
tamination was removed using the DNA-free DNA removal kit (Life Technologies, Inc, Carlsbad, CA). RNA was analyzed using qualitative PCR after DNAase treatment to confirm genomic DNA was removed.

First strand complementary DNA (cDNA) was generated using 2 mcg of RNA with the High-Capacity cDNA Reverse Transcription Kit (10X RT Buffer, 10X Random Primers, 25X 100 mM deoxyNTP mix, and $50 \mathrm{U} / \mathrm{mcL}$ MultiScribe-Reverse Transcriptase; Applied Biosystems, Foster City, CA) with RNAse inhibitor in a reaction volume of $10 \mathrm{mcL}$ as directed. qRT-PCR primers were designed using the IDT PrimerQuest design tool (Integrated DNA Technologies, Coralville, IA; primer sequences are listed in supplemental eTable 4).

qRT-PCR reactions were mixed using $12.5 \mathrm{mcL}$ SYBR Green PCR Master Mix (Applied Biosystems); $1 \mathrm{mcL}$ (10 $\mathrm{mM}$ forward and reverse primers) and $2.5 \mathrm{mcL}$ ( $100 \mathrm{ng} / \mathrm{mcL}$ ) cDNA (250 ng final concentration); and $10 \mathrm{mcL} \mathrm{ddH}_{2} \mathrm{O}$, for a final reaction volume of $25 \mathrm{mcL}$. Reactions were performed in 96well plates. Gene expression was analyzed using the 7300 Real Time System (Applied Biosystems). The qRT-PCR reaction profile was $95^{\circ} \mathrm{C}$ for 30 seconds, $60^{\circ} \mathrm{C}$ for 30 seconds repeated 39 times, $95^{\circ} \mathrm{C}$ for 5 seconds, and melt curve of $65^{\circ} \mathrm{C}$ to $95^{\circ} \mathrm{C}$. All procedures were conducted in Dr. Mohler's laboratory, and the technique was performed with 3 technical replicates and 1 biological replicate, because $\mathrm{BP}$ and $\mathrm{CaP}$ and tissues were collected from 1 patient. Quatification cycle $(\mathrm{Cq})$ values were normalized against $\beta_{2}$ microglobulin (B2M). B2M was selected because BP and $\mathrm{CaP}$ or $\mathrm{B} 2 \mathrm{M}$ gene expression levels remain unchanged during androgen deprivation therapy. Cqs for no reverse transcriptase control and no template controls were reported as undefined. Relative gene abundance was calculated using $2^{\wedge}-(\mathrm{Cq}-\mathrm{B} 2 \mathrm{M})$.

\section{Immunohistochemistry}

Paraffin-embedded prostate tissue sections were deparaffinized and rehydrated under an alcohol gradient, and the antigen was retrieved using Reveal Decloaker (Biocare Medical, Concord, CA) for 30 minutes at $110^{\circ} \mathrm{C}$. Sections were blocked for endogenous peroxidase activity using $3 \% \mathrm{H}_{2} \mathrm{O}_{2}$ in deionized distilled water for 10 minutes at room temperature. Sections probed for either retinol dehydrogenase 16 or caspase-3 were blocked using normal goat serum for 1 hour. Sections stained for $17 \beta$-hydroxysteroid dehydrogenase or ERG were blocked with Biocare Background Punisher (Biocare Medical) for 10 minutes. Sections were incubated in primary antibody at either $4^{\circ} \mathrm{C}$ overnight or for 1 hour at room temperature as indicated (supplemental eTable 5). Sections were incubated for 2 hours with goat anti-mouse, goat anti-rabbit, or rabbit anti-goat. Caspase-3 sections were incubated for 30 minutes at room temperature with rabbit SignalStain Boost IHC Detection Reagent (Cell Signaling, Danvers, MA). Enzymatic activity was revealed using diaminobenzidine (Sigma-Aldrich, St. Louis, MO) and counterstained with hematoxylin (Vector Laboratories, Burlingame, CA). Sections were dehydrated and mounted using permanent mounting medium. Images of stained sections were collected using a Leica DFC0425C camera mounted on a Leica DMRA2 microscope (Leica Microsystems Inc., Buffalo Grove, IL) equipped with an automated stage. ${ }^{14-16}$

\section{Results}

\section{LC-MS/MS Reveals Androgen Levels Were Lower in CaP Than BP Tissues}

Serum testosterone and DHT were at castrate levels in 2005 and 2013 (Figure 1B). Serum DHEA levels were consistent with those reported for men with CaP. ${ }^{17,18}$ TRT in 2014 restored serum testosterone levels to the normal range (Figure 1B), DHEA levels decreased and AND, a degradation product of DHT, and $5 \alpha$-dione, a metabolite of ASD or AND, appeared (Figure 1B). Pregnenolone, dihydroprogesterone, and hydroxyprogesterone, metabolites involved in primary backdoor androgen metabolism and cortisol production, were measurable in serum and levels were consistent with those reported for healthy men (Figure 1C). ${ }^{19}$ Serum cortisol levels were higher than those reported for healthy men (Figure 1D), ${ }^{20}$ which is consistent with the patient's hypertension.

DHT was measurable in BP and CaP tissues (Figure $1 \mathrm{E})$, but testosterone was not measurable, which contrasts with our previous reports that showed DHT and testosterone levels were measurable in all 158 specimens of androgen-stimulated $\mathrm{BP}^{5,21,22}$ and 32 of 33 specimens of CRPC. ${ }^{5,20}$ However, tissue testosterone and DHT levels were similar to those reported for a 74-year-old man who was hypogonadal as a result of testicular trauma that required bilateral orchiectomy at 5 years of age and presented with 
Stocking et al

metastatic $\mathrm{CaP}^{21,23}$ DHT levels were lower in $\mathrm{CaP}$ than BP, but both levels exceeded those reported previously (Figure 1E).,21 DHEA accumulated in $\mathrm{BP}$ and $\mathrm{CaP}$ tissue. Pregnenolone levels were similar in $\mathrm{BP}$ and $\mathrm{CaP}$ tissue; however, cortisol levels were higher in $\mathrm{CaP}$ than $\mathrm{BP}$ tissue (Figure $1 \mathrm{~F}$ ).

\section{Tumor Expression Levels of Androgen Metabolism Enzymes Were Lower in CaP Than BP Tissues}

Androgen metabolism enzyme gene and protein expression levels were measured because these enzymes are involved in all 3 androgen metabolism pathways (Figure 1A). Most androgen metabolism gene expression levels appeared higher in $\mathrm{BP}$ than $\mathrm{CaP}$ tissue (Figure 2A). SRD5A1 and SRD5A3 gene expression were similar between $\mathrm{BP}$ and $\mathrm{CaP}$ tissues. CYP17A1 message levels were not measurable in BP or CaP tissues using qRT-PCR or TrueSeq RNA.

Immunohistochemistry revealed that enzyme protein expression was higher in $\mathrm{BP}$ than $\mathrm{CaP}$ tissue for all
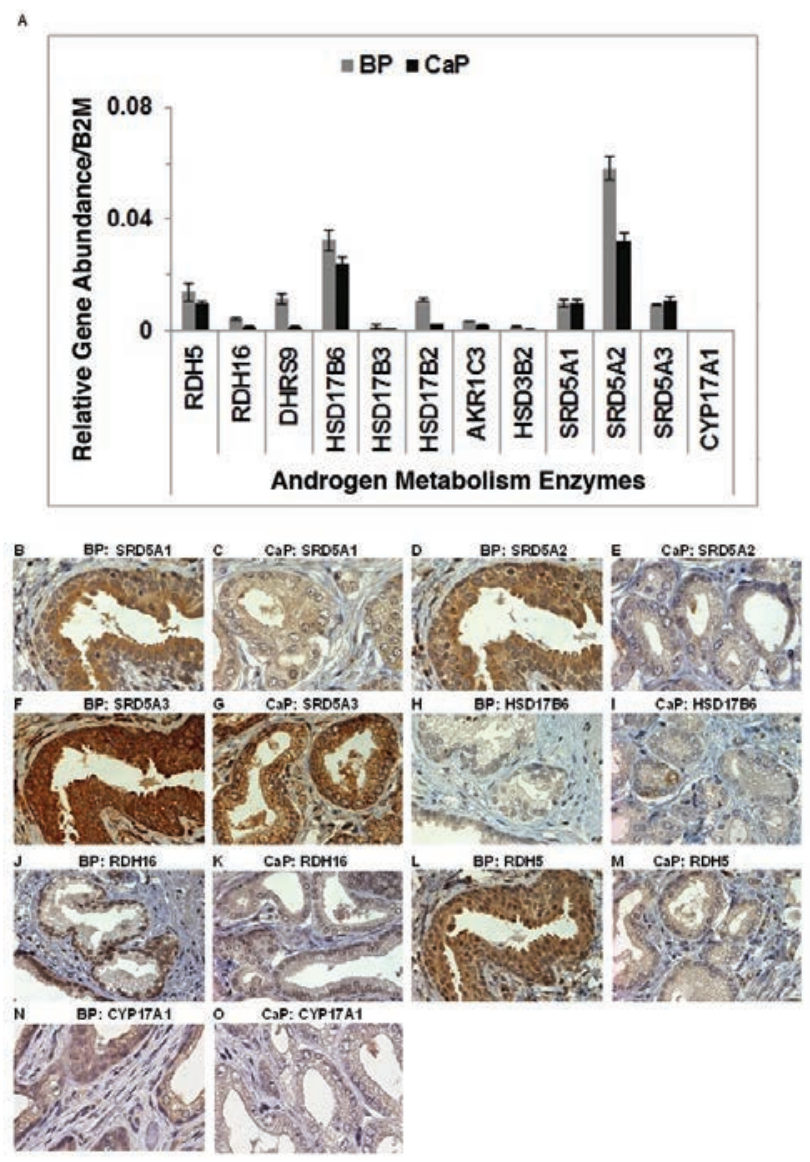

Figure 2. Androgen metabolism enzyme expression. Androgen metabolism expression in BP and CaP tissues: gene (A) and protein (B-O; original magnification $\times 40$ ).

Abbreviations: BP, benign prostate; $\mathrm{CaP}$, protate cancer. other androgen metabolism enzymes (Figure 2B-M). CYP17A1 protein immunostained strongly in BP tissue and weakly in $\mathrm{CaP}$ tissue (Figure $2 \mathrm{~N}$ and $\mathrm{O}$ ).

\section{$A R$ and AR-Regulated Expression Levels Were Lower in CaP Than BP Tissues}

AR expression levels were similar using $N$-terminalor C-terminal-targeted qRT-PCR primers. BP and $\mathrm{CaP}$ samples were analyzed further using RNA-Seq. The trends observed in qRT-PCR data were observed in RNA-Seq data sets (data not shown). AR splice variants were not observed with either qRT-PCR or RNA-Seq (data not shown). AR gene and protein expressions were lower in $\mathrm{CaP}$ than $\mathrm{BP}$ tissues (Figure 3A-C). AR-regulated gene (TMPRSS2, PSA, PTEN, and KLK2) expression levels were lower in $\mathrm{CaP}$ than BP tissues (Figure $3 \mathrm{~A}$ ).

PSA and KLK2 stains were intense and no differences in immunostaining were observed between $\mathrm{BP}$ and $\mathrm{CaP}$ tissues (Figure 3D-G). ERG gene expression was low in $\mathrm{BP}$ and $\mathrm{CaP}$ tissues (Figure 3A).

\section{Discussion}

Eunuchs are surgically castrated men, ${ }^{24}$ and are thought to be incapable of developing functional prostates, benign prostatic hyperplasia $(\mathrm{BPH})$, or $\mathrm{CaP}$.
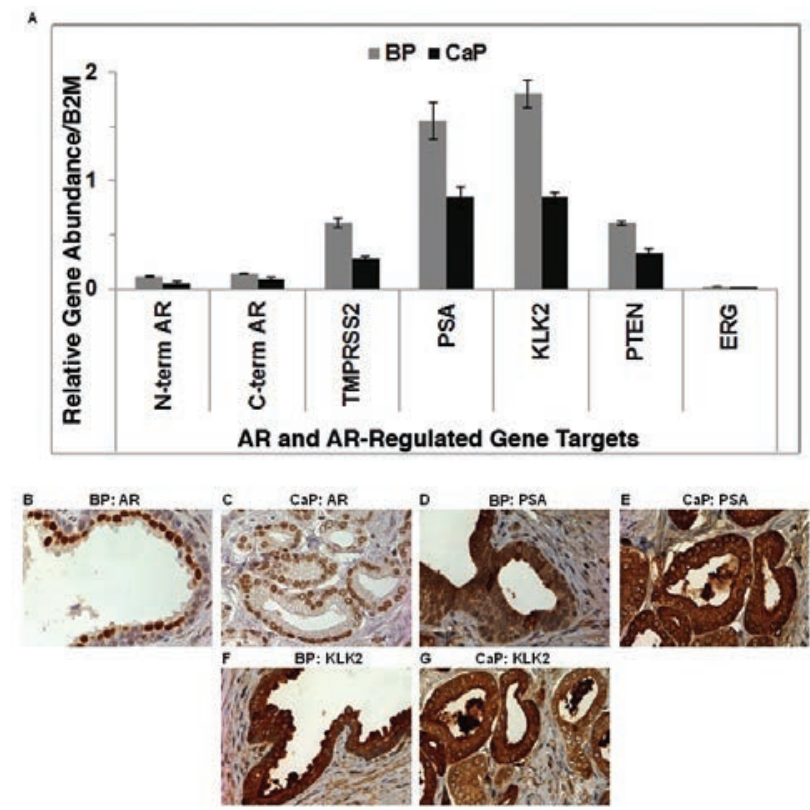

Figure 3. $A R$ and $A R$-regulated expression in $B P$ and $C a P$ tissues: gene (A) and protein (B-G; original magnification $\times 40$ ).

Abbreviations: $A R$, androgen receptor; $B P$, benign prostate; $C a P$, protate cancer; PSA, prostate-specific antigen. 
Huggins $^{25}$ reported that orchiectomy causes a regression of $\mathrm{BPH}$, and that eunuchs, who have castrate levels of circulating androgen, do not develop BPH. Wilson and Roehrborn ${ }^{26}$ describe the prostates of Chinese court, Ottoman court, and Skoptzy eunuchs as being impalpable, atrophic, and prepubertal, respectively.

The patient discussed in the present report lost testicular function before or at the onset of puberty; therefore, the patient is a functional eunuch. The patient presented with clinical Gleason score $4+4=8$ T1cNOM0 CaP that proved to be pathologic Gleason score $3+4=7$ pT3aNOMO CaP after radical prostatecomy, which developed in a testosterone-limited environment. The case provided an opportunity to fully characterize androgen metabolism and ARregulated pathways vital to $\mathrm{CaP}$ development and progression in unique samples.

LC-MS/MS revealed that testosterone was not measurable in either $\mathrm{BP}$ or $\mathrm{CaP}$ tissues, even though it was detectable in serum collected in 2005 and 2013. CaP tissues exhibited DHT levels sufficient for AR activation, but testosterone was undetectable. DHT appears to have been produced by the primary backdoor androgen metabolism pathway and not from androgens synthesized by the adrenal gland. DHEA accumulation observed in $\mathrm{BP}$ and $\mathrm{CaP}$ tissue may be because DHEA is an antagonist against the glucocorticoid pathway, which is evidenced by high levels of serum and tissue cortisol. ${ }^{27,28}$ Tissue ASD levels may be low because ASD is not produced by $\mathrm{BP}$ or $\mathrm{CaP}$ tissues, but requires uptake of adrenalproduced ASD that circulates at very low levels. Any ASD taken up by $\mathrm{BP}$ or $\mathrm{CaP}$ tissues from the circulation was converted directly to testosterone and $5 \alpha$-reduced to DHT or exported from the prostate to the serum. DHT may have been sulfonated ${ }^{29}$ for paracrine reuse or metabolized to androstanediol or AND in BP or CaP tissue. AND and androstanediol can be glucuronidated and trafficked from tissue, ${ }^{30}$ but glucuronidated metabolites may have been expelled more efficiently by BP than CaP cells. Oesterling et $\mathrm{al}^{31}$ reported that adrenal androgens produced by the adrenal gland were not sufficient for prostate growth and development in men diagnosed with hypogonadotropic hypogonadism. DHT tissue levels and $3 \alpha$-oxidoreductase, AR, and AR-regulated gene expression levels were lower in $\mathrm{CaP}$ than $\mathrm{BP}$ tissues. CYP17A1, an androgen metabolism enzyme that plays a key role in adrenal androgen synthesis, was not detected using qRT-PCR, and low protein expression levels were detected in $\mathrm{BP}$ and $\mathrm{CaP}$ tissues. CYP17A1 gene and protein expression levels may differ due to tight regulation of RNA. CYP17A1 activity was reported to be enhanced by phosphorylation $^{32}$; enhanced enzyme activity may have initiated a negative feedback response to downregulate CYP17A1 RNA levels when protein levels reached an expression level threshold. DHT levels were sufficient for AR transactivation. ${ }^{5,21}$

\section{Conclusions}

BP used intracrine androgen metabolism to create the microenvironment necessary for the development of $\mathrm{CaP}$ that exhibited an androgen metabolism profile similar to that reported previously for CRPC. ${ }^{21}$ The patient's PSA level remained unchanged since radical prostatectomy despite normalization of circulating testosterone using TRT. LC-MS/MS, qRT-PCR, and immunohistochemistry data prove that the patient's BP and $\mathrm{CaP}$ tissue depended on the primary backdoor pathway to generate DHT.

\section{References}

1. Siegel RL, Miller KD, Jemal A. Cancer statistics, 2016. CA Cancer J Clin 2016;66:7-30

2. Heinlein CA, Chang C. The roles of androgen receptors and androgenbinding proteins in nongenomic androgen actions. Mol Endocrinol 2002;16:2181-2187.

3. Kohli M, Tindall DJ. New developments in the medical management of prostate cancer. Mayo Clin Proc 2010;85:77-86.

4. Huggins C, Hodges CV. Studies on prostatic cancer: I. The effect of castration, of estrogen and androgen injection on serum phsphatases in metastatic carcinoma of prostate. Cancer Res 1941;1:293-297.

5. Titus MA, Schell MJ, Lih FB, et al. Testosterone and dihydrotestosterone tissue levels in recurrent prostate cancer. Clin Cancer Res 2005;11:46534657 .

6. Mohler JL, Titus MA, Bai S, et al. Activation of the androgen receptor by intratumoral bioconversion of androstanediol to dihydrotestosterone in prostate cancer. Cancer Res 2011;71:1486-1496.

7. Chang KH, Li R, Papari-Zareei M, et al. Dihydrotestosterone synthesis bypasses testosterone to drive castration-resistant prostate cancer. Proc Natl Acad Sci U S A 2011;108:13728-13733.

8. Auchus RJ. The backdoor pathway to dihydrotestosterone. Trends Endocrinol Metab 2004;15:432-438.

9. Titus MA, Gregory CW, Ford OH III, et al. Steroid 5alpha-reductase isozymes I and II in recurrent prostate cancer. Clin Cancer Res 2005;11:4365-4371.

10. Helpap B, Egevad L. The significance of modified Gleason grading of prostatic carcinoma in biopsy and radical prostatectomy specimens. Virchows Arch 2006;449:622-627.

11. Morrison C, Cheney R, Johnson CS, et al. Central quadrant procurement of radical prostatectomy specimens. Prostate 2009;69:770-773.

12. Wilton JH, Titus MA, Efstathiou E, et al. Androgenic biomarker profiling in human matrices and cell culture samples using high throughput, electrospray tandem mass spectrometry. Prostate 2014;74:722-731. 
13. Guidance for Industry: Bioanalytical Method Validation. Available at: http://www.fda.gov/downloads/Drugs/Guidance/ucm070107.pdf. Accessed july 26, 2016.

14. Gregory CW, Hamil KG, Kim D, et al. Androgen receptor expression in androgen-independent prostate cancer is associated with increased expression of androgen-regulated genes. Cancer Res 1998;58:5718-5724.

15. Mohler JL, Morris TL, Ford OH III, et al. Identification of differentially expressed genes associated with androgen-independent growth of prostate cancer. Prostate 2002;51:247-255

16. Kim D, Gregory CW, French FS, et al. Androgen receptor expression and cellular proliferation during transition from androgen-dependent to recurrent growth after castration in the CWR22 prostate cancer xenograft. Am J Pathol 2002;160:219-226.

17. Stahl F, Schnorr D, Pilz C, et al. Dehydroepiandrosterone (DHEA) levels in patients with prostatic cancer, heart diseases and under surgery stress. Exp Clin Endocrinol 1992;99:68-70.

18. Kim W, Zhang L, Wilton JH, et al. Sequential use of the androgen synthesis inhibitors ketoconazole and abiraterone acetate in castrationresistant prostate cancer and the predictive value of circulating androgens. Clin Cancer Res 2014;20:6269-6276.

19. Giton F, Trabado S, Maione L, et al. Sex steroids, precursors, and metabolite deficiencies in men with isolated hypogonadotropic hypogonadism and panhypopituitarism: a GCMS-based comparative study. J Clin Endocrinol Metab 2015;100:E292-296.

20. Kraan GP, Dullaart RP, Pratt JJ, et al. The daily cortisol production reinvestigated in healthy men. The serum and urinary cortisol production rates are not significantly different. J Clin Endocrinol Metab 1998;83:12471252.

21. Mohler JL, Gregory CW, Ford OH III, et al. The androgen axis in recurrent prostate cancer. Clin Cancer Res 2004;10:440-448.

22. Mohler JL, Gaston KE, Moore DT, et al. Racial differences in prostate androgen levels in men with clinically localized prostate cancer. J Urol 2004;171(6 Pt 1):2277-2280
23. Arai S, Shibata Y, Nakamura Y, et al. Development of prostate cancer in a patient with primary hypogonadism: intratumoural steroidogenesis in prostate cancer tissues. Andrology 2013;1:169-174

24. Min KJ, Lee CK, Park HN. The lifespan of Korean eunuchs. Curr Biol 2012;22:R792-793.

25. Huggins C. The etiology of benign prostatic hypertrophy. Bull N Y Acad Med 1947;23:696-704.

26. Wilson JD, Roehrborn C. Long-term consequences of castration in men: lessons from the Skoptzy and the eunuchs of the Chinese and Ottoman courts. J Clin Endocrinol Metab 1999;84:4324-4331.

27. McNelis JC, Manolopoulos KN, Gathercole LL, et al. Dehydroepiandrosterone exerts antiglucocorticoid action on human preadipocyte proliferation, differentiation, and glucose uptake. Am J Physiol Endocrinol Metab 2013;305:E1134-1144.

28. Sacco M, Valenti G, Corvi Mora P, et al. DHEA, a selective glucocorticoid receptor antagonist: its role in immune system regulation and metabolism. J Endocrinol Invest 2002;25(10 Suppl):81-82.

29. Mueller JW, Gilligan LC, Idkowiak J, et al. The regulation of steroid action by sulfation and desulfation. Endocr Rev 2015;36:526-563.

30. Olsson M, Ekstrom L, Guillemette C, et al. Correlation between circulatory, local prostatic, and intra-prostatic androgen levels. Prostate 2011;71:909-914

31. Oesterling JE, Epstein JI, Walsh PC. The inability of adrenal androgens to stimulate the adult human prostate: an autopsy evaluation of men with hypogonadotropic hypogonadism and panhypopituitarism. J Urol 1986;136:1030-1034.

32. Lamb DC, Waterman MR. Unusual properties of the cytochrome P450 superfamily. Philos Trans R Soc Lond B Biol Sci 2013;368:20120434.

\section{See JNCCN.org for supplemental online content.}

